\title{
Changing Perceptions of the Value of Daughters and Girls' Education among the Isoko of Nigeria
}

\author{
Patrick A. Edewor \\ Department of Sociology \\ Covenant University \\ P. M. B. 1023, Ota \\ Ogun State, Nigeria
}

\begin{abstract}
This paper examines the changes in parents' perception on the value of daughters and their education. It utilizes information generated from Focus Group Discussions in two urban and four rural Isoko communities in Delta State, southern Nigeria. Eight Focus Groups were constituted in each of the towns and villages (four for men and four for women). The groups were homogeneous in terms of sex, age and educational level. It is observed that parents' perception on the value of daughters is changing because adult daughters have been found to be more caring and more supportive of aged parents than adult sons. Consequently, parents now consider the education of daughters as very rewarding since educated daughters become better equipped to provide support to their parents. The changing attitudinal disposition towards girls' education has implication for the enhancement of women's status and fertility decline.
\end{abstract}

Key Words: Changing perceptions, value of daughters, girls' education, women's status, fertility, Isoko, Nigeria

\section{Introduction}

The preference for male children is one of the major causes of high fertility in most countries of Africa (Isiugo-Abanihe, 1994a; 1994b). The preference for a particular sex derives from the perceived value or benefits of that particular sex to parents (Karki, 1988). Among the Isoko of Delta State, southern Nigeria, as in many parts of Nigeria, male children are valued for their role in retaining or perpetuating family name, staying permanently in or near family compound or residence, provision of old-age security and serving as a source of defence and social prestige to parents. When young, male children render assistance to their parents in terms of helping on the farm, helping parents in their businesses, running errands and, to a lesser extent, performing some household chores. On the other hand, female children particularly assist their mothers in a range of household chores including cooking, washing plates and clothes, sweeping and cleaning house as well as baby minding (Edewor, 2001; Orubuloye, 1987). 
Parents' perceptions of these benefits of male and female children influence their fertility attitudes and preferences as well as actual fertility. The preference for sons causes parents to have many children in the bid to have at least a son to perpetuate family name and also to inherit family property (Orubuloye, 1987; Isiugo-Abanihe, 1994a; 1994b; Edewor et al, 1997; Edewor, 2001).

Although the traditional role of female children and women still persists in several spheres, changes are beginning to occur in parents' perception on the value of daughters and the status of women in Isoko society. These changing perceptions are altering the attitudinal disposition of parents towards girl children in general and girl's education in particular. Education has been one major area in which girls have been systematically more disadvantaged than boys, simply because of gender discrimination which often begins at the earliest stages of life (United Nations, 1994). Traditional beliefs and practices are often at the root of this gender gap. Girls are kept at home to supplement family welfare by working and caring for siblings and household (Muller, 2000).

Aside from these, in many developing countries, daughters are withdrawn from schools at puberty, for fear of unwanted pregnancy, and are married off early to husbands they do not necessarily want (Muller, 2000). This gender discrimination in education is not limited to the less developed countries of Africa. In some parts of Asia, as in China, continued and fast economic growth is not accompanied by dramatic change in traditional value, and many peasants still hold son preference value. For example, utilizing census data and drawing on ethnographic fieldwork in Beijing and its suburbs, Wang (2005) examined children's educational opportunities and observed that continued son preference value, based on traditional views and perceived financial returns to families, leads to a lower educational attainment among daughters. This was particularly so in the rural areas of China. Yet, as the Progress of Nations (UNICEF, 1994) asserts:

There is widespread agreement that the education of girls is one of the most important investments that any developing country can make in its own future. In the long term, almost every other aspect of progress, from nutrition to family planning, from child health to women's rights, is profoundly affected by whether or not a nation educates its girls. 
A number of reasons account for the preference for the education of boys relative to girls. First, sons typically are responsible for supporting parents in their old age. This, therefore, makes the education of sons more attractive to parents. As such the costs of education, both direct costs (e.g. school fees, books, uniforms, etc.) and opportunity costs (e.g. loss of household help and in some cases, wages) are more readily absorbed for

sons than daughters (Hadden and London, 1996). Second, the thought that girls, upon marriage, join their husband's family and take with them the benefits of education, makes parents to have little incentives to bear the costs of educating their daughters (Hill and King, 1993; Bellew et al., 1992; Herz et al., 1991; Mensch and Lloyd, 1997, Edewor, 2001). These constraints to female education operate almost exclusively at the household level (Hadden and London, 1996).

In their study of the demographic, basic needs and economic benefits of educating girls in the third world, Hadden and London (1996) have observed that both boys and girls must have equal access to primary and secondary education if education is to have the desired depressive effect on fertility. They also made a similar observation with respect to health and mortality. Primary and secondary education of boys or girls had mortality reducing and, by implication, health enhancing effects. Girls' education had the strongest impact on infant and child mortality. This is not surprising as females usually have most direct responsibility over infants and children. Infant and child mortality had the greatest reductions in countries where both boys and girls have similar enrolment rate in primary and secondary school but these reductions were either lost or diminished in those countries in which girls' enrolment lagged behind those of boys. Hadden and London (1996) concluded that in the third world, education in general, and girls' education in particular, has wide ranging beneficial effects on the demographic, social and economic development patterns of nations. Despite these benefits of girls' education, preference had always been given to boys' education in most traditional African societies including the Isoko society of Nigeria. However, parents are beginning to be aware of the benefits of daughters and are thus changing their perceptions on the value of daughters and girls' education. This paper examines the role of girl children and women in traditional Isoko society, the changing perceptions on the value of daughters and girls' schooling as well as the implication of these for the status of women and fertility. 


\section{Methods}

Isoko people inhabit two Local Government Areas namely: Isoko North and Isoko South in Delta State of Nigeria. With the exception of the two Local Government Headquarters (Ozoro and Oleh), all other communities in the area are rural. The information on which this paper is based was generated from Focus Group Discussions conducted in the two urban areas (Oleh and Ozoro) and four other rural areas (Aviara, Emevor, Olomoro and Oyede) Isoko communities of Delta State, southern Nigeria. The Focus Group Discussions were on parents' perception on the value of children. Eight groups (four for men and four for women) were constituted in each community. The groups were homogeneous in terms of sex, age and educational level of participants. Thus, the groups for men comprised men aged 20-39 years with primary or less education (young men with low level of education); men aged 20-39 years with secondary or more education (young men with high level of education); men aged 40-60 years with primary or less education (old men with low level of education); and men aged 40-60 years with secondary or more education (old men with high level of education).

The groups for women comprised women aged 15-29 years with primary or less education (young women with low level of education); women aged 15-29 years with secondary or more education (young women with high level of education); women aged 30-49 years with primary or less education (old women with low level of education); and women aged 30-49 years with secondary or more education (old women with high level of education). There were 48 groups altogether. Each group was composed of between six and ten persons and each discussion session lasted for about an hour.

Topics discussed include, among other things, the importance of children to parents, attitude to childlessness and infertility, the role of parents and their responsibilities toward children in the past and present as well as advantages and disadvantages of large and small number of children. Other themes covered include ideal and desired family size, sex preference, education of male and female children in the past and present as well as the types of help normally rendered by male and female children when young and when they have become adults. The rest of this paper is devoted to findings on aspects related to the topic of this paper and it focuses mainly on the role of female children and women in traditional Isoko society, the changing perceptions on the value of daughters, and 
consequently, the changing perceptions on girls' education. These are discussed vis-à-vis the implications for women's status, empowerment and fertility.

\section{The role of female children and women in traditional Isoko society}

The Isoko society is, basically, a patriarchal and patrilineal one characterized by the dominance of men in virtually all spheres of life. Women in traditional Isoko society were expected to be subservient to their husbands. Men's views on family matters and reproduction took the upper hand over those of women. The social norms which supported these gender relations were culturally transmitted from one generation to another through the process of socialization. From childhood, a girl internalized these social norms, including those that defined women's status as subordinate to those of men. She grew up to become an "obedient" and "good" wife so to speak. Female autonomy was virtually non-existent.

The Isoko society was, and still is, basically rural with agriculture as the main occupation. Crops mainly grown are cassava, yam, maize, plantain (as food crops) and rubber (as a cash crop). Owing to the dominance of oil palm in the vegetation of the area, oil palm collection for palm oil processing is widely engaged in. Fishing is also a major occupation among those who live near the Ase River which bounds the area on the eastern part (Ikime, 1971).

Division of labour in traditional Isoko society was mainly on the basis of gender. While farm brushing and land preparation, including the making of ridges, was mainly the work of men (assisted by their sons), women and daughters did the planting, weeding, harvesting, processing and marketing of farm produce. The wives and daughters of men who were palm collectors also assisted in carrying bunches of harvested palm fruits to processing units and also marketed the palm oil after processing. With the advent of schooling, male children were given the opportunity of attending school while the female children remained at home, either baby-minding or assisting their mothers in the above mentioned activities and frying gari (cassava flour), the major food processing activity in the area. These activities, together with the low value attached to girl's education, as we shall soon show, accounted for the preference for sons' education. Greater value was placed on sons, whose education was perceived to be more beneficial to parents than that of daughters. The perceived value of daughters to parents is, however, changing as discussed in the next section. 


\section{Changing perceptions on the value of daughters}

The changing perceptions on the value of daughters among parents in Isoko society basically derives from the realization of the immense benefits of daughters to parents. Both fathers and mothers have come to realize that there is nothing a boy can do that a girl cannot do for parents. Indeed, there is a general consensus among both men and women that female children are of greater benefits to parents, in many respects, than male children. This is in the sense that they have been found to be more caring for aged parents; they visit parents more regularly and they give more financial support to parents

than do adult male children. Discussing the helps normally rendered by female children when young and when they have become adults, male Focus Group Discussants aged 40 - 60 years (with primary or less education) in Oleh (an urban community and the Local Government Headquarters for Isoko South), gave the following responses:

Mr. A: Young female children assist in the performance of household chores: They sweep the house, fetch water and follow their parents to the farm.

Mr. B: When they have become adults and are married, they send food and clothing to their parents.Mr. C: The adult female children care more for their parents than do their male counterparts. When the male children have become married, they tend to care more for their wives, children and in-laws.

Discussing the helps rendered by female children when young and when they have become adults, Ozoro women aged 15 - 29 years (with primary or less education) had this to say with respect to young female children:

Mrs. A: They help in hawking and selling in market stalls. They also help with the cooking until their parents return from farm. They render these helps after returning from school.

Mrs. B: They help their mother in the performance of household chores such as cooking, sweeping and washing plates and clothes. 
Patrick A. Edewor: Changing Perceptions of the Value of Daughters and Girls' 61 Education among the Isoko of Nigeria

When the female children have become adults,

Mrs. A: They could visit their parents from their husband's house, and if the mother is ill, they clean up the house and wash the parents' clothes, cook and leave money behind. They could even buy a bag of rice for the parents.

Mrs. B: It is exactly the way she has said it. Girls easily remember parents than boys do. Girls are more rewarding these days. In the past, it was boys they considered beneficial.

In Oyede, a rural community, men aged 20 - 39 years (with primary or less education) expressed the following views:

Mr. A: Adult girls normally favour their mother more than their father. They mostly send hot drinks to their father. I have two sisters who are married to Urhobo men. They always send hot drinks to my father. I even helped him to sell two of such recently. But they always send wrappers to my mother. Before they could send one dress the father, they would have sent about three to the mother. So, they cheat the fathers.

Mr. B: They normally send money to the parents. They are more caring than their male counterparts. This may be as a result of the fact that they have changed names.

They also visit the parents on a regular basis. When the parents are sick, they visit and spend quality time with them. The male would only stay for a day, provide the drugs and off he goes. 
Adult sons are normally saddled with a lot of responsibilities the moment they get married. They bear most of the costs of raising their children, including the costs of children's food, the costs of children's education, the costs of children's medical care, the costs of housing and that of transport. Only the costs of children's clothing are mainly borne by their wives (Edewor, 2001).

As a result of the greater proportion of these costs borne by adult married sons, it is extremely difficult for them to meet their parents' expectations regarding provision of financial support and other kinds of expected help. However, parents seem to be of the view that male children are simply not caring. This is not to say that adult male children do not render help to their aged parents. The point is that, relative to adult daughters, they render less assistance and they are not as sympathetic and caring as adult female children. Not only do female children pay regular visits, they stay with their parents for a longer period when they visit, especially when the parents are sick. They show more affection and provide more financial support than sons do to their parents. As a result of these perceived benefits of daughters, the preference for male children appears to be gradually declining although not completely obliterated. The changing perceptions on the value of daughters are also reflected in a changing perception on the education of girls.

\section{Changing perceptions on girls' schooling}

Participants in Focus Groups were asked to comment on the attitude of parents towards the education of male and female children in the past and present and also account for the changing perceptions among parents, on the education of male and female children. In Ozoro (an urban community and Local Government Headquarters for Isoko North), men aged 40 - 60 years with primary or less education remarked as follows on the education of male and female children in the past and present:

Mr. A: In the past, it was boys that were mainly sent to school. This was because it was thought that the girl would merely be educated for her husband. But nowadays, it is even better to train a girl than to train a boy. 
Patrick A. Edewor: Changing Perceptions of the Value of Daughters and Girls' 63 Education among the Isoko of Nigeria

Mr. B: One should train his children irrespective of sex. It is the ones that are level-headed that should be trained.

Mr. C: I have a son who already has children. I also have a daughter who finished from secondary school. She is now married. She sends money to me but the boy doesn't send anything. He only concentrates on his wife and children. Is it not better to train girls?

Mr. D: After the boys marry and have children, they forget you.

Mr. E: It depends on one's destiny. Some boys look after their parents and some girls don't. That is why one should have both sex and also have many children.

In the same community, women aged $30-49$ years with secondary or more education made the following remarks:

Mrs. A: In the past, it was boys that were mainly sent to school. It was felt that if the girls were sent to school, they would become pregnant and their schooling would be terminated and the money spent on their education would become wasted. That was why girls were not sent to school in the past. But parents now send them to school. It is only those who are not intelligent that go to learn a trade.

Mrs. B: It was also felt that an educated girl would eventually be given out in marriage and she would change name. If she becomes a news caster on radio, it is her husband's name that would be popularized, not that of the person who educated her. These were the reasons why girls were not sent to school in the past. But nowadays, girls are trained to any level as long as the ability is there. 
64 African Population Studies Vol. $21 n^{\circ} 1 /$ Etude de la population africaine vol. $21 n^{\circ} 1$

Mrs. C: It was ignorance that made people not to send their girls to school in the past because even after a girl is married, she could still be of benefit to you.

Mrs. D: It was actually ignorance. People have now realized that a daughter is more rewarding than a son. The moment a boy gets married, he would only concentrate on his wife and in-laws. But a girl would always remember her parents. Even though girls still get pregnant in school, when they give birth, they continue

with their schooling. I know a girl in class 4 who got pregnant. After she had the baby, her mother had to take over the baby so she could return to school.... Many women who did that for their daughters who got pregnant in school are now enjoying the benefits.

Still in the same town, a female discussant in a group whose members were aged $30-49$ years with primary or less education remarked as follows:

In the past, when people gave birth to children, they needed

to have both male and female children. The practice was that only male children were sent to school. But we have now discovered that the education of girls is more rewarding than that of boys. This is because the girl can send the wrapper or dress she is no more using to you, the mother. But the boys, they only concentrate on their in-laws.... Because of this, I would rather send my daughter to a higher institution than do my son. All the wrappers I have at home were brought to me by my daughters.

In Oyede (a rural community in Isoko North LGA), men aged 20 - 39 years with primary or less education gave the following responses as they discussed on the education of male and female children in the past and present. 
Mr. A: In the past, preference was given to the education of boys because it was felt that the moment a girl gets married, she leaves for another family; she would leave for her husband's place. But nowadays, things are no longer so. The education of boys and girls is rewarding.

Mr. B: Another reason why it was thought that the education of a girl was a waste is that it was felt that her education would end up in the kitchen. While the boys went to school, the girls were made to stay at home to look after their younger siblings. But now, we have realized the importance of sending girls to school because if you get to offices and you see educated women neatly dressed and with a pen in their hand, matching round the whole place, you will admire them. One would regret not having sent her daughter to school.

Mr. C: Another thing is that because farming is our main occupation, the girls did a lot of weeding of farms. When the boys went to school, the girls were taken to the farm and it was one of the hindrances to girls' education. But nowadays, as the boys wear their shorts to go to school, the girls also wear their skirts and do the same.

Mr. D: Another reason is that a lot of these girls got pregnant in school after spending so much on their education. Such money became wasted and this discouraged a lot of parents on the education of girls. Although girls still get pregnant in school today, when they put to bed, the parents collect the baby while the girls go back to school. This is because parents have realized that an educated daughter would be very helpful in future. 
The above remarks represent the views expressed by Focus Group Discussants in all the other communities covered in this study. As can be seen, preference was given to sons' education in the past. Female children were not sent to school because it was felt that their education would ultimately benefit their husbands and not the girls' parents or immediate kins. Orubuloye (1987) and Edewor et al (1997) had made similar observations among the Yoruba. It was felt that a woman's education only ends up in the kitchen. Besides, parents felt that it was not worth it after all because girls soon got married and changed names; after acquiring a high level of education, a girl goes on to project the name of her husband's family rather than her own father's name. Aside from these, parents entertained the fear of their daughters becoming pregnant in school and consequently causing the financial investment in their education to become wasted. Premarital pregnancy was rampart especially among the few daughters who went to school. Pregnancy could, and in actual fact did, terminate girls' schooling. This brought discouragement to parents who would have been interested in sending their daughters to school, even in spite of the then perceived lower benefits derivable from girls' schooling.

Tremendous changes have, however, occurred with respect to girls' education. Almost equal opportunities are now given to both boys and girls in terms of their education. The preference for sons' education is fast disappearing. Parents have now realized that the education of female children could equally be as rewarding, in fact more rewarding than that of male children. There was a general consensus among Focus Group Discussants that the non-education of female children in the past was as a result of ignorance on the part of parents. Although pre-marital sex is rampant among school girls, perhaps even on the increase, a lot of girls know how to prevent a pregnancy. In the event that pregnancy occurs, it

could be terminated. Pregnancies not terminated are carried to term and the girl returns to school after delivery. Whereas pregnancy and child birth abruptly terminated a girl's schooling in the past, things have changed. The mothers of such girls receive the baby while the girl goes back to school.

A major benefit of children to parents in the past and present is that of the provision of old-age security. In parental calculations, an educated child becomes equipped to provide his/her parents with support - especially financial support - at old age. Parents who strove to ensure that their children acquired substantial education, especially up to the tertiary level, 
did so mainly because of the expectation of future reward or gain that would accrue to them (the parents) and the social prestige associated with being the father or mother of a highly placed person in society. Education remains the major tool or avenue for upward social mobility.

Parents appear to have realized that education enhances the status of women in society, who in turn, are better equipped to provide their parents with the much needed old-age security support. The realization among Isoko parents, of the fact that adult daughters are sympathetic towards their aged parents and the fact that they have been found to be more supportive than their male counterparts, makes it economically rational, in parental calculations, to invest in girls schooling.

Children remain the major source of old-age support among Isoko people. Rural respondents and women more readily mention children as a means of old-age support. In a survey of Isoko people, Edewor (2001) observed that 96 percent of the respondents expect financial help from their children; 91 percent would still expect such help from children after the children have become married. Women and rural respondents are more likely to expect financial help from children. Expectation of financial help is, however, inversely related to education, income and age at first marriage while it is positively related to ideal and desired family size. These expectations, and more importantly, the perceived benefits of adult female children in the present day, majorly account for the changing perceptions on the value of daughters and, consequently, the changing perceptions on the value of girls' education, given the fact that adult female children are meeting these obligations more than adult male children.

\section{Implications for women's status and fertility}

The realization of the importance of girls' education, which has resulted in increased female participation in education, has far reaching implications for the status of women ${ }^{1}$. As observed earlier, education remains the main tool for social mobility and the major instrument for the enhancement of social status. Given the fact that education enhances a person's status, it is expected that with more widespread schooling for female children, Isoko women would, in the future, have their status changed for the better. 
Education is also a major tool for the political and economic empowerment of women. The empowerment of women has been noted to be a step in the right direction toward the improvement of women's reproductive health. This is because it brings about a more egalitarian relationship in reproductive decision-making. Education would liberate women from such harmful traditional practices as female genital mutilation and their marginalized position. It would reduce gender inequality and make women to contribute their quota to the development process of the nation.

Changes in the perception on the value of daughters and the status of women as well as increased female enrolment in schools have far reaching consequences for fertility. It is a known fact that education is negatively associated with fertility, in part because education raises women's age at marriage, erodes traditional family size norms and promotes knowledge and use of family planning. Education is also positively associated with a more egalitarian relationship between spouses as well as greater inter-spousal communication regarding family size and contraceptive use. Educated women also participate more in fertility decision-making. Greater participation of women in fertility decision-making and inter-spousal communication on family size and contraceptive use are also associated with lower fertility (Isiugo-Abanihe, 1994b). It is, therefore, expected that the changing perception of parents on the value of daughters and consequently, their education would cause fertility to decline in the future.

Moreover, one of the reasons why fertility is high in third world countries, particularly Africa, is the preference for male children. Couples without male children tend to continue childbearing until they have at least one male child. With a changing attitudinal disposition toward the girl child, it is expected that high fertility due to sex preference reasons (the preference for the male child) would gradually begin to wane. Persistently high fertility in the face of declining mortality has been the major cause of rapid population growth in Nigeria and in most less developed countries of the world. By implication, the changing perception on the value of daughters and the changing status of women, resulting from education, would, among other things, contribute to stemming the rapid growth of the country's population through the decline in fertility. 


\section{Conclusion}

The changing perception on the value of daughters among parents in Isoko society is altering their attitudes toward the benefits of girls' education. Given the fact that parents perceive adult daughters as more caring and

more supportive than adult sons, girls' education is perceived as a way of investing for the future. Educated women are better equipped to provide support to their aged parents. This changing perception on the value of daughters creates a favourable disposition towards girls' education. This positive disposition has implication for the enhancement of women's status and fertility reduction.

\section{End Note}

1 In this study, no attempt was made to investigate male and female enrolment rates in the primary and secondary schools in the study area in order to determine the degree to which female enrolment in schools has caught up with or surpassed that of male. It is important that further study should examine this in order to determine the extent to which the changing perception on girls' education actually translates into increased female enrolment.

\section{References}

Bellew, R.; Raney, L. and Subbarao, K. (1992) "Educaing girls." Finance and Development, 29:1 (March), 54-56.

Edewor, P. A.; Ademiluyi, I. A.; Okosun, G. (1997) The Value of Children as a Determinant of Reproductive Behaviour in Ogun State, Nigeria. A research report submitted to Population Research Fund (PRF), NISER, Ibadan.

Edewor, P. A. (2001) Fertility and The Value of Children among The Isoko of Delta State, Nigeria, Ph.D Theses, University of Ibadan, Ibadan.

Hadden, K. and London, B. (1996) "Educating girls in the Third World; the demographic, basic needs, and economic benefits." International Journal of Comparative Sociology, 37:1-2. 
70 African Population Studies Vol. $21 n^{\circ} 1 /$ Etude de la population africaine vol. $21 n^{\circ} 1$

Herz, B.; Subbarao, K.; Habib, M. and Raney, L. (1991) Letting Girls Learn: Promising Approaches in Primary and Secondary Education, World Bank Discussion Papers, No. 133. Washington, DC: World Bank.

Hill, M. A. and King, E. M. (1993) “Women's education in developing countries: An overview." In: King, E. M. and Hill, M. A. (eds.) Women's Education in Developing Countries. Baltimore and London: The Johns Hopkins University Press.

Ikime, O. (1972) The Isoko People: A Historical Survey. Ibadan: University of Ibadan Press.

Isiugo-Abanihe, U. C. (1994a) "The socio-cultural context of high fertility among Igbo women". International Sociology. June, 9 (2): 237-258.

Isiugo-Abanihe, U. C. (1994b) "Reproductive motivation and family size preferences among Nigerian men". Studies in Family Planning. May/June; 25 (3): 149-161.

Karki, Y. B. (1988) "Sex preference and the value of sons and daughters in Nepal". Studies in Family Planning. May/June; 19 (3): 169-178.

Mensch, B. S. and Lloyd, C. B. (1997) "Gender differences in the schooling experiences of adolescents in low-income countries: The case of Kenya." Policy Research Division Working Paper No. 95. New York: Population Council.

Muller, A. (2000) "Women and girls: education, not discrimination." OECD Observer, a: 223.

Orubuloye, O. (1987) "Values and costs of daughters and sons to Yoruba mothers and fathers". In: Oppong, C. (ed.) Sex Roles, Population and Development in West Africa. Portsmouth, New Hampshire: Heinemann. 85-90.

UNICEF (1994) The Progress of Nations. New York: UNICEF House.

United Nations (1994) Programme of Action of the United Nations International Conference on Population and Development. New York: Post Conference Draft Report, September 19.

Wang, W. (2005) "Son preference and educational opportunities of children in China - Who wants you to be born a girl?" Paper presented at the 37th World Congress of International Institute of Sociology. July 5-9, Stockholm, Sweden. 